\title{
Design of joints of thin sheet parts with mechanical connections (according to EN 1993-1-3)
}

\author{
Mirosław BRONIEWICZ*1, Sandra MLONEK ${ }^{1}$, and Romuald SZELĄG ${ }^{1}$ \\ ${ }^{1}$ Faculty of Civil Engineering and Environmental Sciences, Bialystok University of Technology, Bialystok, Poland
}

\begin{abstract}
The main direction of development of steel building structures is to reduce the cost of implementation of buildings without changing their load-bearing capacity and value in use. Therefore, an essential factor in the development is the introduction of modern technologies. Solutions from other industries such as automotive or aerospace, have been adapted to perform building structures. As a result, today in the construction industry we use lightweight steel profiles from cold-bent elements. Modern technology and advanced calculation theory make it possible to build these structures much more economically than previous conventional systems. Elements and products made of thin sheets allow to reduce costs of construction, but at the same time is associated with the possibility of defects resulting in the appearance of a state of failure of structural elements or the entire facility. Connection zones of thin-walled elements are always the critical points, hence the need for a particularly thorough assessment at the design stage, and then at the implementation of the investment. Correct application of the presented calculation procedure in article will allow the design and realization of modern structures, which will be durable and safe in operation for the expected period of time.
\end{abstract}

Keywords: mechanical connections, bolted connections, screw connections, steel constructions, steel profiles.

\section{General Information}

The main direction of development of steel building structures is to reduce the cost of implementation of buildings without changing their load-bearing capacity and value in use. Therefore, an essential factor in the development is the introduction of modern technologies. Solutions from other industries such as automotive or aerospace, have been adapted to perform building structures. As a result, today in the construction industry we use lightweight steel profiles from cold-bent elements. Modern technology and advanced calculation theory make it possible to build these structures much more economically than previous conventional systems. Elements and products made of thin sheets allow to reduce costs of construction, while providing quick commissioning of the object. All parts of the structure and its cladding (external walls, internal walls, ceilings and roofs) are factory-made. They are light during assembly, perfectly adapted for easy fitting and mutual juxtaposition as well as fastening by uncomplicated joining elements.

According to EN 1993-1-3 [8], forming interconnections of cold-formed elements should follow the same rules as for hot-rolled elements. When designing the connections, the following should be taken into account [1, 3, 10]:

- internal forces, occurring in the bars or discs to be joined,

- shear resistance of the elements (webs and flanges) and the connectors

- the cross-sections of least resistance in the connected parts,

- overall behaviour of the node or joint under load, consisting in the assessment of its instantaneous stiffness and ultimate rotational capacity,

- the deformation capacity of the joint or its parts during the manufacture of the elements and their assembly and the operation of the structure under the conditions of use of the building or the structure.

\footnotetext{
*Corresponding author: E-mail address: m.broniewicz@pb.edu.pl (Mirosław BRONIEWICZ)
} 
- Eccentricities and stress concentration points,

The verification of the resistance of the junctions and joints to the internal forces acting on them is carried out for lightweight bended section elements or profiled sheeting according to the same principles as for normal structures [8].

Connections should be designed on the basis of a reasonably assumed distribution of internal forces (longitudinal and transverse forces and bending moments), taking into account the influence of the relative stiffnesses of the parts in the node and contact area. These forces and moments should be transmitted directly through the joint parts (including the fasteners). The conditions of equilibrium between the forces and moments acting on the connection and the stresses in the parts of both the node (contact) and the additional fasteners (plates, washers, caps, angles, etc.) must be fulfilled. [2, 4, 7].

\section{Bolted connections}

When connecting thin sheets or walls of curved sections, bolts with full shank rolled threads can be used. The bolt is then pressed against the hole wall practically via the threaded part. Bolts of shank diameter from 6 to 16 mm of class 4.8 to 10.9 may be used. Traditionally, it is recommended to take the bolt diameter from the relationship:

$$
2 t \leq d \leq 3 t
$$

In which:

$\mathrm{t}$ - the thickness of the thinner of the sheets to be joined.

Given the recommendation that the connection is sufficiently ductile, bolt shank thicknesses should be chosen closer to the upper limit given by equation (1).

In shear connections, the resistance of the bolt is determined by:

- shank shear:

- with reference to classes 4.6, 5.6 i 8.8:

$$
\begin{aligned}
& F_{v, R d}=0.6 A_{s} f_{u b} / \gamma_{M 2} \\
& F_{v, R d}=0.6 A_{s} f_{u b} / \gamma_{M 2}
\end{aligned}
$$

- with reference to classes 4.8, 5.8, 6.8 and 10.9:

$$
F_{v, R d}=0.5 A_{s} f_{u b} / \gamma_{M 2}
$$

- pressure (ovalisation of the hole or breakage of the sheet ):

$$
F_{b, R d}=2.5 \alpha_{b} k_{t} f_{u} d t / \gamma_{M 2}
$$

- breakage of a net sheet section:

$$
\begin{gathered}
F_{n, R d}=\left[1+3 r\left(d_{o} / u-0.3\right)\right] A_{n e t} f_{u} d t / \gamma_{M 2} \\
F_{n, R d}=A_{n e t} f_{u} /\left(n_{f} \gamma_{M 2}\right)
\end{gathered}
$$

whereas:

$\alpha_{b}=1.0 \mathrm{lub} \alpha_{b} \leq e_{1} /(3 d), k_{t}=(0.8 t+1.5) / 2.5$ przy $0.75 \leq \mathrm{t} \leq 1.25 \mathrm{~mm}, \mathrm{k}_{t}=1.0$ przy $\mathrm{t}>1.25 \mathrm{~mm}, \mathrm{~d}-\mathrm{bolt}$ shank diameter, $\mathrm{d}_{o}$ - bolt hole diameter, $\mathrm{e}_{1}$ - distance from the fastener axis to the sheet metal edge in the direction of loading, $\mathrm{r}=\mathrm{n}_{1} / \mathrm{n}_{f}, \mathrm{n}_{1} \mathrm{n} 1$ - number of bolts in the cross-section, $\mathrm{n}_{f}$ - total number of bolts in the connection, 
$\mathrm{u}=2 \mathrm{e}_{2}$ but $\mathrm{u} \leq \mathrm{p}_{2}, \mathrm{e}_{2}$ - distance from the fastener axis to the sheet metal edge perpendicular to the load direction, $\mathrm{p}_{2}$ - distance between fastener axes in direction as before, $\mathrm{A}_{n e t}$ - - net sectional area of the sheet, $\gamma_{M 2}=1.25-$ partial safety factor.

For shear connections, the following conditions must be met:

$$
F_{v, R d} \geq 1.2 F_{b, R d} \quad \text { oraz } \quad F_{v, R d} \geq 1.2 F_{n, R d}
$$

In case of $\mathrm{t} \geq 3 \mathrm{~mm}$ instead of using formula (4), the relationships indicated in PN-EN 1993-1-8 [9] should be used.

The conditions according to (8) should be met when the deformation capacity of the joint is necessary. If these conditions are not met, the joint should be designed so that the necessary deformation capacity is provided by other parts of the structure.

In tension connections, the resistance of the bolt is determined by:

- pulling the bolt head through the sheet:

$F_{p, R d}$ should be determined on the basis of test results,

- bolt shank breakage:

$$
F_{t, R d}=0.9 f_{u b} A_{s} / \gamma_{M 2}
$$

whereby the condition must be met:

$$
F_{t, R d} \geq F_{p, R d}
$$

The formulas given for evaluating the resistance of a bolt are valid when the clearances in the connections are within: $\mathrm{e}_{1} g e q 1,0 \mathrm{~d}_{o}, \mathrm{e}_{2} \geq 1.5 \mathrm{~d}-o, \mathrm{p}_{1} \geq 3 \mathrm{~d}_{o}, \mathrm{p}_{2} \geq 3 \mathrm{~d}_{o}$, and moreover $f_{u} \leq 550 \mathrm{MPa}$ and $3,0 \mathrm{~mm}>\mathrm{t}_{1} \geq 0,75 \mathrm{~mm}$.

The number of bolts in the connection is determined from the relation:

$$
n_{f}=\frac{F_{t, E d}}{\min \left(F_{p, R d}, F_{t, R d}\right)}, n_{f}=\frac{F_{v, E d}}{F_{v, R d}}
$$

or

$$
n_{f}=\frac{F_{t, E d}}{\min \left(F_{p, R d}, F_{t, R d}\right)}
$$

Frictional connections or bolts must be secured against loosening under shock or vibration loads. If the connection is subjected to varying shear loads, or if slippage of the connection is unacceptable, then a friction connection or a slip fit should be used.

\section{Screw connections}

Screws are used to join profile (folded) sheets overlapping and with hot-rolled or cold-formed sections, and longer ones to join sandwich panels with purlins or wall rafters. PN-EN 1993-1-3 [8] gives requirements and formulas for the calculation of joints for self-tapping screws. However, the conditions of behavior under load of self-drilling threads are analogous. Therefore, the formulae given hereafter can also be applied to any kind of screws.

In shear connections, the load capacity of the screw is determined by:

- shank shear: $\mathrm{F}_{v, R d}$ should be determined on the basis of test results.

- pressure (ovalisation of the hole or breakage of the sheet metal):

$$
F_{b, R d}=\alpha d t_{1} f_{u} / \gamma_{M 2}
$$


- rupture of the net section of a sheet:

$$
F_{n, R d}=A_{n e t} f_{u} / \gamma_{M 2}
$$

whereas: $\alpha=3.2(\mathrm{t} / \mathrm{d})^{0.5}$ but $\alpha \leq 2.1$, when $\mathrm{t}=\mathrm{t}_{1}, \alpha=3.2(\mathrm{t} / \mathrm{d})^{0.5}$, but $\alpha \leq$ when $\mathrm{t}<1.0 \mathrm{~mm}$ and $\mathrm{t}_{1} \geq 2.5 \mathrm{t}, \alpha-$ is determined from linear interpolation when $\mathrm{t}<\mathrm{t}_{1}<2.5 \mathrm{t}, \mathrm{t}-$ the thickness of the thinner of the sheets to be joined, $\mathrm{t}_{1}$ - thickness of the thicker of the sheets to be joined.

Shear strength of screws $\mathrm{F}_{v, R d}$ should be determined experimentally whereas:

$$
F_{v, R d}=F_{v, R k} / \gamma_{M 2}
$$

In shear connections, the conditions must also be met (8).

In tension connections, the screw resistance is determined by:

- pulling the screw head through the sheet:

- under static load:

$$
F_{p, R d}=d_{w} t f_{u} / \gamma_{M 2}
$$

- under wind load:

$$
F_{p, R d}=0.5 \quad d_{w} t f_{u} / \gamma_{M 2}
$$

- pulling out of the ground:

$$
\begin{aligned}
& F_{o, R d}=0.45 \quad d t_{\text {sup }} f_{u, \text { sup }} / \gamma_{M 2}, \quad g d y \quad t_{\text {sup }} / s \leq 1 \\
& F_{o, R d}=0.65 \quad d t_{\text {sup }} f_{u, \text { sup }} / \gamma_{M 2}, \quad g d y \quad t_{\text {sup }} / s>1
\end{aligned}
$$

- shank breakage: $F_{t, R d}$ should be determined on the basis of test results,

whereas: $\mathrm{d}_{w}$ - washer or connector head diameter, $\mathrm{s}$ - pitch of the thread line, $\mathrm{t}_{\text {sup }}$ - the thickness of the substrate in which the fastener is to be fixed. In addition, conditions should be checked:

$$
F_{t, R d} \geq F_{p, R d} \quad \text { oraz } \quad F_{t, R d} \geq F_{o, R d}
$$

Conditions (19) should be met when the deformation capacity of the connection is required. If these conditions are not met, the connection shall be designed so that this necessary capacity is obtained in other parts of the structure.

The given formulas for evaluating the resistance of a screw are valid when the spacings in the connections are within: $\mathrm{e}_{1} \geq 3{ }_{d}, \mathrm{e}_{2} \geq 1.5 \mathrm{~d}, \mathrm{p}_{1} \geq 3 \mathrm{~d}, \mathrm{p}_{2} \geq 3 \mathrm{~d}$, in tension, however, additional conditions must be met: $0.5 \mathrm{~mm} \leq \mathrm{t} \leq$ $1.5 \mathrm{~mm}, \mathrm{t}_{1} \geq 0.9 \mathrm{~mm}, f_{u} \leq 550 \mathrm{MPa}$.

There are no recommendations for screw diameter selection in PN-EN 1993-1-3 [8] or company catalogs. However, taking into account the general guidelines, it is desirable that the diameter of the screw shank should not be too small, preferably: $6 \mathrm{t}<\mathrm{d}<10 \mathrm{t}$. 


\section{Examples of calculations}

Example 1: Verify the resistance of the connection at the support of zeta purlins made of Z300x75/65x21x3 sections made of S320GD $+Z$ steel with yield strength $f_{y b}=320 \mathrm{~N} / \mathrm{mm}^{2}$ and strength $f_{u}=390 \mathrm{~N} / \mathrm{mm}^{2}$ (Fig. 1). The purlin is continuously loaded with $\mathrm{q}_{d}=4,2 \mathrm{kN} / \mathrm{m}^{2}$. The support moment is $\mathrm{M}_{e d}=46.0 \mathrm{kNm}$, while the support reaction $\mathrm{V}_{e d}=43,8 \mathrm{kN}$. The connection of the $\mathrm{z}$-bars above the support is made by overlapping with bolts M16 x 4.8 class $\mathrm{B}$ (medium-fine workmanship) with strength $f_{u b}=420 \mathrm{kN} / \mathrm{mm}^{2}$, threaded on the whole length of the shank, embedded in holes of the diameter $\mathrm{d}_{0}=18 \mathrm{~mm}$. The effective cross-sectional area of the boltcore is $\mathrm{A}_{s}=1.57 \mathrm{~cm}^{2}$.

The bolt load is determined with :

- due to shank shear:

$$
F_{v, R d}=0.5 A_{s} f_{u b} / \gamma_{m 2}=0.5 \cdot 157 \cdot 420 / 1.25=26380 N=26.4 k N
$$

- due to ovalization of the hole or rupture of the purlin sheet:

$$
\begin{gathered}
\alpha_{b}=\min [1.0 ; 40 /(3 \cdot 16)=0.83]=0.835, k_{t}=1.0 \quad \text { przy } \quad t=3 \mathrm{~mm}>1.25 \\
F_{b, R d}=2.5 \cdot \alpha_{b} \cdot k_{t} \cdot f_{u} \cdot d \cdot t / \gamma_{M_{2}}=2.5 \cdot 0.83 \cdot 1.0 \cdot 390 \cdot 16 \cdot 3 / 1.25=31080 \mathrm{~N}=31.1 \mathrm{kN}
\end{gathered}
$$

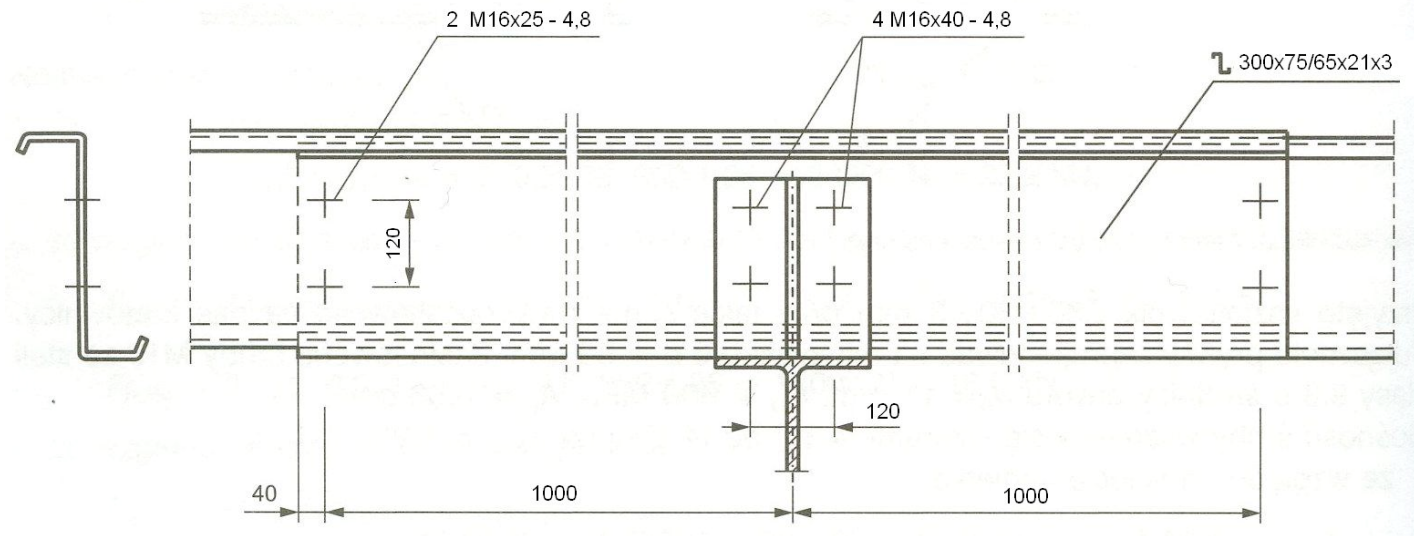

Figure 1. Purlin connection at the support

Verification of the load carrying capacity of the bending moment bolts. From the equation of equilibrium of the bending moments about the support point, the following is obtained:

$$
\begin{gathered}
2 \cdot F_{v, E d 1} \cdot a+0.5 \cdot q_{d} \cdot a^{2}-M_{E d}=0 \\
F_{v, E d 1}=\left(M_{E d}-0.5 \cdot q_{d} \cdot a^{2}\right) / 2 a=\left(46.0-0.5 \cdot 4.2 \cdot 1.0^{2}\right) / 2 \cdot 1.0=22.0 k N
\end{gathered}
$$

Verification of the load capacity condition:

$$
F_{v, E d}=26.4 k N>F_{V, E d 1}=22.0 k N
$$

Checking the load capacity of bolts carrying the support reaction:

$$
V_{E d}=43.8 k N<4 \cdot F_{v, E d}=4 \cdot 26.4=105.6 k N
$$


Example 2: Verify the load capacity of the tension connection of a T60/235x1.25 mm folded sheet to a purlin (Fig. 2 ). The sheet is made of S350GD steel of strength $f_{u}=390 \mathrm{~N} / \mathrm{mm}^{2}$. The sheet was placed in the negative position and loaded with wind suction. The connection was made using WSS-5.5x32 self-drilling screws with neoprene washers of diameter $\mathrm{d}_{w}=16 \mathrm{~mm}$, with a pull-out load capacity $\mathrm{F}_{o, R d}=2.64 \mathrm{kN}$. The wind suction load per connector is $\mathrm{F}_{t, E d}$ $=2.14 \mathrm{kN}$.

Load capacity of a screw due to pulling the screw head through the sheet under wind load and static load:

$$
F_{p, R d}=0.5 d_{w} t f_{u} / \gamma_{M 2}=0.5 \cdot 16 \cdot 1.25 \cdot 390 / 1.25=3120 N=3.1 k N>F_{t, E d}=2.14 k N
$$

The pull-out load capacity of the screw, when the support is not susceptible, is:

$$
F_{o, R d}=2.64 k N>F_{t, E d}=2.14 k N
$$

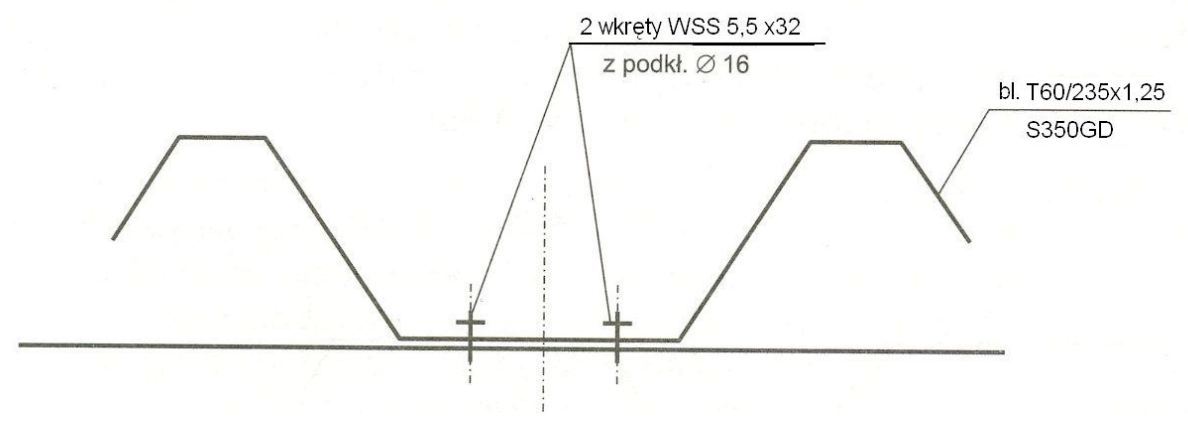

Figure 2. Connection of folded sheets subjected to wind suction

Verification of the support resistance to bending due to concentrated forces from the connectors. The width of the supporting strip of the sheet is assumed asb $=120 \mathrm{~mm}$. Bending moment from a load applied at a point on the edge of the washer:

$$
M_{R d}=\frac{120 \cdot 1.25^{2}}{6} \frac{350}{1.0}=10900 \mathrm{Nmm}=10.9 \mathrm{kNmm}<M_{E d}=27.8 \mathrm{kNmm}
$$

The bending resistance of the sheet metal is insufficient. The support is susceptible. Therefore two connectors must be used, spaced next to each other. As the connectors are on two quarter lines, the capacity should be reduced by multiplying by 0.7 (see Figure 8.2 of EN 1993-1-3) [8]:

$$
r e d F_{o, R d}=0.7 \cdot 2.14=1.5 k N>0.5 F_{t, E d}=1.07 k N
$$

Example 3: Verify the load capacity of an overlap joint between T160/195x1.25 mm profiled sheets made of S350 GD steel of strength $f_{u}=390 \mathrm{~N} / \mathrm{mm}^{2}$, of support moment per 1 linear meter of sheet width is $\mathrm{M}_{E d}=21 \mathrm{kNm}$ (rys. 3 ). The distance of the connectors from the support is a $=280 \mathrm{~mm}$. The connection is made with self-tapping screws WSS $5 \times 5 \times 32 \mathrm{~mm}$ of shear resistance $\mathrm{F}_{v, R d}=4.25 \mathrm{kN}$.

Lateral force per $195 \mathrm{~mm}$ wide fold.

$$
V_{E d} \cdot a=0.5 \cdot 0.195 / 1.0 \cdot M_{E d}, \quad \text { stad } \quad V_{E d}=0.5 \cdot 0.195 \cdot 21.0 / 0.28=7.31 k N
$$

Design resistance of the screw due to pressure against the hole wall:

$$
\begin{gathered}
\alpha=3.2(t / d)^{0.5}=3.2(1.25 / 5.5)^{0.5}=1.52<2.1 \\
F_{b, R d}=\alpha d t f_{u} / \gamma_{M 2}=1.52 \cdot 5.5 \cdot 1.25 \cdot 390 / 1.25=3260 \mathrm{~N}=3.3 k N
\end{gathered}
$$




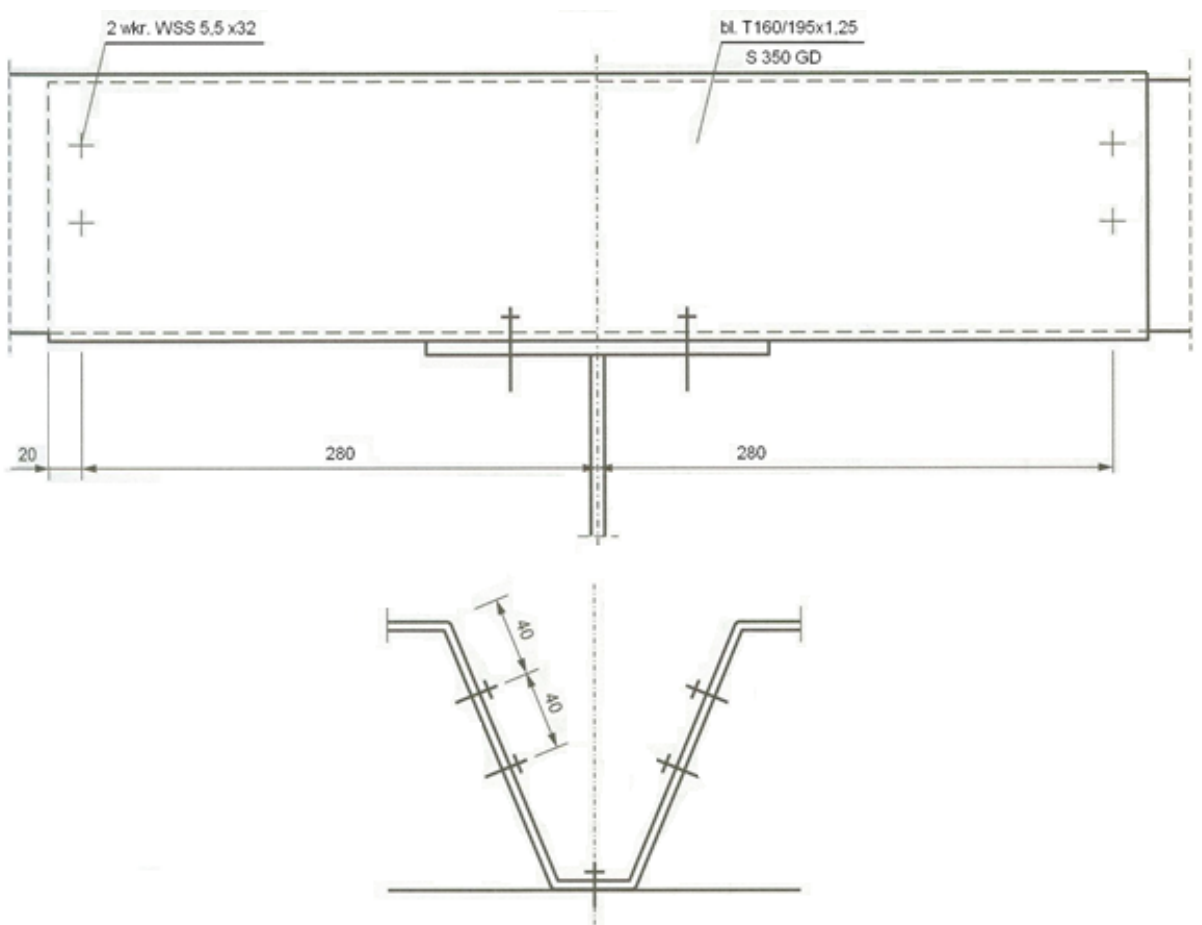

Figure 3. Lap joint of profiled sheeting over a support

Number of screws required:

$n=7.31 / 3.3=2.2$

Assumed 4 screws per fold.

Example 4 Calculate the resistance of a bolted connection in a lattice truss node, shown in Fig. 4 of a x-brace loaded with a larger longitudinal force $\mathrm{N}_{E d}=18.0 \mathrm{kN}$, of S235. The connection is single-cut. The section adopted is C60x30x2 mm and the same two sections for the strip of the truss. The connection of bars is designed on the eccentric $\mathrm{e}=30 \mathrm{~mm}$. M10 bolts of 8.8 grade steel with hole diameter were used $\mathrm{d}_{o}=11 \mathrm{~mm}, f_{u b}=800 \mathrm{MPa} \mathrm{A}_{s}=0.58 \mathrm{~cm}^{2}$.

The bolt load is determined with $\gamma_{m 2}=1.25$. Due to:

- shank shear:

$$
F_{v, R d}=0.6 A_{s} f_{u b} / \gamma_{m 2}=0.6 \cdot 58 \cdot 800 / 1.25=22270 N=22.27 k N
$$

- ovalization of the hole or breaking the sheet:

$$
\begin{gathered}
\alpha_{b}=\min [1.0 ; 15 /(3 \cdot 10)=0.5]=0.5, k_{t}=1.0 \quad \text { przy } \quad t=2 \mathrm{~mm}>1.25 \mathrm{~mm} \\
F_{b, R d}=2.5 \cdot 0.5 \cdot 1.0 \cdot 10 \cdot 2 \cdot 360 / 1.25=7200 \mathrm{~N}=7.2 \mathrm{kN}
\end{gathered}
$$

- section net breakage (at $r=1 / 2=0.5, u=2 \cdot 14=28 \mathrm{~mm}$ ):

$$
F_{n, R d}=\left[1+3 \cdot 0.5\left(\frac{11.0}{28.0}-0.3\right)\right] \cdot 2.0(30-2-11) \cdot 360 /(2 \cdot 1.25)=5580 \mathrm{~N}=5.58 \mathrm{kN}
$$

and

$$
F_{n, R d}=2.0 \cdot(30-2-11) 360 /(2 \cdot 1.25)=4900 N=4.90 k N
$$




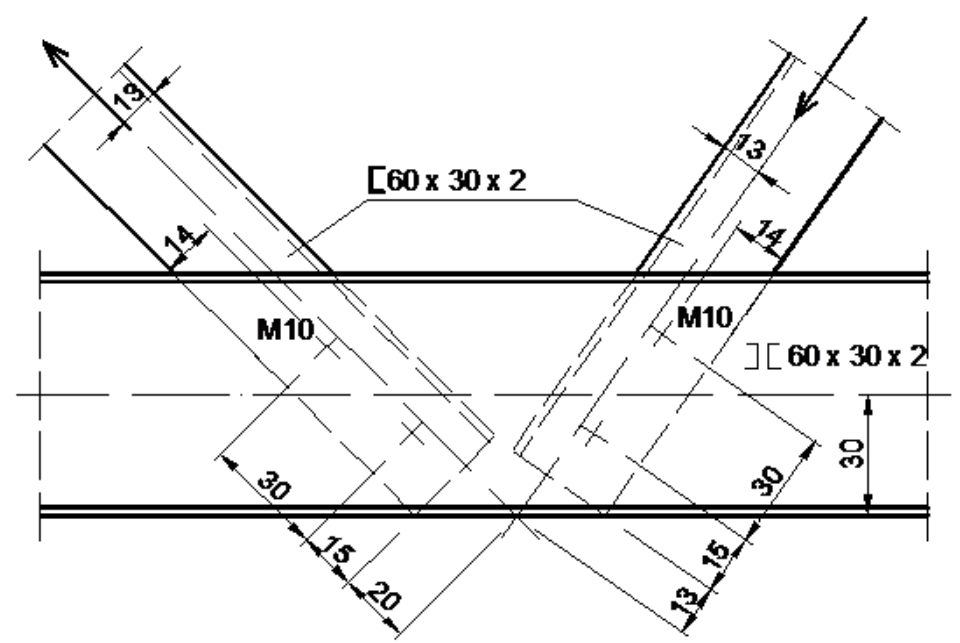

Figure 4. Bolt connection of the lattice truss

Additional conditions:

$22.27 \mathrm{kN}>1.25 \cdot 7.2 \mathrm{kN}=9.0 \mathrm{kN}$,

$22.27 \mathrm{kN}>1.25 \cdot 4.90 \mathrm{kN}=6.13 \mathrm{kN}$.

Bolt and $\mathrm{x}$-brace axis eccentricity $e=30-13-14=3 \mathrm{~mm}$ :

$M_{E d}=18000 \cdot 3=54000 \mathrm{Nmm}$.

The forces acting on one bolt are:

$$
F_{v, R d, N}=\frac{18000}{2 \cdot 2}=4500 N=4.5 k N, \quad F_{v, R d, M}=\frac{54000}{2 \cdot 30}=900 N=0.9 k N
$$

The resultant of forces in the bolt:

$$
F_{v, R d}=\sqrt{F_{v, R d, N}^{2}+F_{v, R d, M}^{2}}=\sqrt{4.5^{2}+0.9^{2}}=4.59 k N<4.90 k N
$$

\section{Summary}

Common introduction to the use of modern technologies results from the need to effectively minimize the costs and time of investment implementation. Introduction of innovative solutions should be preceded by a widespread educational campaign among designers and building contractors. The use of lightweight steel profiles, made of cold-bent elements, allows for a reduction in investment costs, but at the same time is associated with the possibility of defects resulting in the appearance of a state of failure of structural elements or the entire facility. Connection zones of thin-walled elements are always the critical points, hence the need for a particularly thorough assessment at the design stage, and then at the implementation of the investment. Control processes at the stage of use, resulting from current legislation, also require the use of individual testing procedure [6].

In the course of several years, the authors have analyzed cases of disasters of objects of steel structure. For example, the factor influencing the unsafe condition of the superstructure were defects in the design of steel purlins. Thin sheet metal of the superstructure, with thickness not exceeding $1.0 \mathrm{~mm}$, was commonly fixed with dowels located at distances exceeding $1.0 \mathrm{~m}$. The sheeting made in this way was not equivalent to a rigid shield providing sufficient stiffness to the full roof slope due to the possibility of a screw or dowel head pulling through the sheeting under wind and static loads. In the static calculations of purlins, whether made of rolled sections or cold-formed sheet metal, no account was taken of the effect of the possibility of losing the flat bending form on the reduction in strength. The load carrying capacity of purlins constructed in this way was much lower than that required to safely carry the acting loads $[5,11]$. 
Correct application of the presented calculation procedure will allow the design and realization of modern structures, which will be durable and safe in operation for the expected period of time.

\section{References}

1. Bogucki, W. \& Żyburtowicz, M. Tablice do projektowania konstrukcji metalowych (Arkady, Warszawa, 2006).

2. Bródka, J. \& Broniewicz, M. Projektowanie konstrukcji stalowych zgodnie z Eurokodem 3-1-1 wraz z przykładami obliczeń (Wydawnictwa Politechniki Białostockiej, Białystok, 2001).

3. Bródka, J., Broniewicz, M. \& Giżejowski, M. Ksztattowniki gięte: poradnik projektanta (Polskie Wydawnictwo Techniczne, Rzeszów, 2006).

4. Bródka, J., Kozłowski, A., Ligocki, I., Łaguna, J. \& Ślęczka, L. Projektowanie $i$ obliczanie połaczeń $i$ węzłów konstrukcji stalowych (Polskie Wydawnictwo Techniczne, Rzeszów, 2008).

5. Krentowski, J. R., Szeląg, R. \& Tribiłło, R. Rozwiązania inżynierskie w procesie adaptacji obiektów przemysłowych. Inżynieria i Budownictwo 64, 150-152 (2008).

6. Krentowski, J. R. \& Knyziak, P. Evaluation aspects of building structures reconstructed after a failure or catastrophe. IOP Conf. Series: Materials Science and Engineering 245, 1-10 (2017).

7. PN-EN 1993-1-1 Eurokod 3: Projektowanie konstrukcji stalowych - Część 1-1: Reguły ogólne i reguły dla budynków

8. PN-EN 1993-1-3 Eurokod 3: Projektowanie konstrukcji stalowych - Część 1-3: Reguły ogólne - Reguły uzupełniajace dla konstrukcji z kształtowników i blach profilowanych na zimno.

9. PN-EN 1993-1-8 Eurokod 3: Projektowanie konstrukcji stalowych-Część 1-8: Projektowanie węzłów.

10. Tomaszewicz, D. \& Baryłka, A. Influence of measuring deviations of the components of layered walls on their durability. Inżynieria Bezpieczeństwa Obiektów Antropogenicznych 3, 155-162 (2020).

11. Łaguna, J. \& Łypacewicz, K. Połaczenia śrubowe i nitowe (Arkady, Warszawa, 1986). 